\title{
PENGARUH PIJAT BAYI TERHADAP PENINGKATAN MOTORIK KASAR DAN MOTORIK HALUS BAYI USIA 3-24 BULAN DI KLINIK FISIOTERAPI SUDIANG MAKASSAR
}

\author{
Suharto, Suriani, Arpandjam'an \\ Jurusan Fisioterapi Politeknik Kesehatan Makassar
}

\begin{abstract}
ABSTRAK
Saat ini masalah yang dihadapi anak usia kurang 1 tahun adalah masalah perkembangan geraknya, seperti keterlambatan perkembangan motorik. Oleh karenanya perkembangan anak perlu mendapat perhatian lebih, utamanya bagi para orang tua sejak usia dalam kandungan hingga usia dewasa. Jenis penelitian ini adalah penelitian pra eksperimen dengan desain penelitian one group pre-test dan post-test yang dilaksanakan di Klinik Fisioterapi Sudiang Makassar. Populasi penelitian ini adalah semua bayi $3-24$ bulan yang berkunjung di Klinik Fisioterapi Sudiang selama periode penelitian dan sampel penelitian dengan cara accidental sampling selama penelirtian sebanyak 20 orang. Hasil penelitian diperoleh keemampuan mengontrol lengan dengan nilai $p=0.000$, kemampuan mengontrol badan dengan nilai $p=0.001$, kemampuan mengontrol tungkai diperoleh nilai $p=0.004$ dan kemampuan koordinasi jari tangan diperoleh nilai $\mathrm{p}=0.004$. Kesimpulan penelitian ini bahwa pemijatan bayi usia $3-24$ bulan berpengaruh terhadap peningkatan kemampuan mengontrol lengan, badan, tungkai bawah dan koordinasi jari tangan
\end{abstract}

Kata Kunci : Pijat Bayi, Perkembangan motorik

\section{PENDAHULUAN}

Setiap anak adalah individu yang unik, karena faktor bawaan dan lingkungan yang berbeda, maka pencapaian kemampuan perkembangannya juga berbeda tetapi tetap akan mengikuti pola umum perkembangan. Diperkirakan lebih dari 20 juta anak balita di Negara berkembang gagal mencapai potensi perkembangan optimalnya karena masalah kemiskinan, malnutrisi, atau lingkungan yang tidak mendukung, sehingga mempengaruhi perkembangan kognitif, motorik, emosi, dan sosial anak. ( Rahmita P. Soendjojo, 2010).

Pembentukan kualitas SDM yang optimal, baik sehat secara fisik maupun psikologis sangat bergantung dari proses tumbuh dan kembang pada usia dini. Anak yang sehat akan menunjukkan tumbuh kembang yang optimal apabila diberikan lingkungan bio-fisiko-psikososial yang adekuat, namun sebagian besar masyarakat belum memahami hal ini terutama mereka yang mempunyai tingkat pendidikan dan sosial ekonomi yang relatif rendah (Nursalam, 2005).

Saat ini masalah yang dihadapi anak usia kurang 1 tahun adalah masalah perkembangan geraknya, seperti keterlambatan perkembangan motorik. Oleh karenanya perkembangan anak perlu mendapat perhatian lebih, utamanya bagi para orang tua sejak usia dalam kandungan hingga usia dewasa. Dimana proses ini berbeda antara satu dengan yang lainnya tergantung dari faktor pendukung, baik itu faktor genetik maupun faktor lingkungan.

Menurut Soetdjiningsih (2012), perkembangan merupakan periode penting dalam kehidupan anak khususnya setelah melewati masa perkembangan sangat pesat pada usia tiga tahun. Usia tiga tahun merupakan batas telah melewati perkembangan sangat cepat atau sering disebut masa kritis perkembangan. Setelah masa ini perkembangan akan berlangsung secara kontinyu, maka perlu dilakukan deteksi dini pertumbuhan dan perkembangan seorang anak usia tiga tahun agar cepat terdeteksi gangguan perkembangannya untuk landasan perkembangan selanjutnya.

Data angka kejadian keterlambatan perkembangan umum belum diketahui dengan pasti, namun diperkirakan sekitar 1-3\% anak di bawah usia 6 tahun mengalami keterlambatan perkembangan umum. Pada tahun 2010 sekitar $35,4 \%$ anak balita di Indonesia menderita penyimpangan perkembangan seperti penyimpangan dalam motorik kasar, motorik halus, serta penyimpangan mental emosional. Pada tahun 2011 berdasarkan pemantauan status tumbuh kembang balita, prevalensi tumbuh kembang turun menjadi $23,1 \%$. Hal ini disebabkan karena Indonesia mengalami kemajuan dalam program. ( Riskesdas, 2013). Untuk mengatasi permasalahan keterlambatan perkembangan motorik ini, 
dapat diberikan pijat bayi anggota gerak anak untuk menstimulasi perkembangan motoriknya agar perkembangannya sesuai dengan usianya, karena pijat bayi dapat merangsang otot - otot, tulang dan sistem organ untuk berfungsi secara maksimal.

Berdasarkan uraian tersebut diatas, maka dilakukan penelitian lebih lanjut untuk mengetahui Pengaruh Pijat Bayi terhadap Peningkatan Motorik Kasar dan Motorik Halus Bayi Usia 3-24 Bulan Di Klinik Fisioterapi Sudiang Makassar.

\section{METODE PENELITIAN}

Jenis penelitian ini adalah penelitian pra eksperimen dengan desain penelitian one group pre-test dan post-test yang dilaksanakan di Klinik Fisioterapi Sudiang Makassar. Populasi penelitian ini adalah semua bayi $3-24$ bulan yang berkunjung di Klinik Fisioterapi Sudiang selama periode penelitian dan sampel penelitian dengan cara accidental sampling selama penelirtian sebanyak 20 orang.

Pengumpulan data dilakukan dengan cara mencatat identitas subjek penelitian anak kemudian diukur perkembangan motorik anak dengan menggunakan skala bayley. Pada tahap pelaksanaan setiap anak diukur nilai perkembangan motoriknya kemudian diberikan pijat bayi. Setelah 8 kali perlakuan lalu diukur lagi perkembangan motoriknya.

\section{HASIL PENELITIAN}

1.Karakteristik Subjek Penelitian

Sampel yang didapatkan memiliki rentang umur $6-18$ bulan dengan jenis kelamin laki-laki sebanyak 9 orang $(45 \%)$ dan perempuan sebanyak 11 orang $(55 \%)$.

2. Kemampuan Motorik Kasar dan halus setelah diberikan Pijat Bayi

Data yang diperoleh adalah nilai perkembangan motorik berupa kemampuan mengontrol lengan sebelum dan sesudah pemijatan. Pengukuran kemampuan mengontrol lengan dilakukan dua kali dengan menggunakan skala Bayley. Untuk lebih jelasnya hasil penelitian kemampuan motorik kasar dan halus pada subjek penelitian dapat dilihat pada tabel . di bawah ini.

Tabel .Kemampuan Motorik Kasar dan halus setelah diberikan Pijat Bayi

\begin{tabular}{|l|c|c|c|c|c|}
\hline \multirow{2}{*}{ Variabel } & \multicolumn{2}{|c|}{ Mean } & \multicolumn{2}{c|}{ PD } & \\
\cline { 2 - 5 } & Pretest & Postest & Pretest & Postest & \\
\hline $\begin{array}{l}\text { Kemampuan mengontrol } \\
\text { Lengan }\end{array}$ & 4,70 & 7,85 & 1,13 & 2,92 & 0,000 \\
\hline Kemampuan mengontrol Badan & 2.85 & 5.05 & 3.63 & 3.94 & 0.001 \\
\hline $\begin{array}{l}\text { Kemampuan mengontrol } \\
\text { Tungkai }\end{array}$ & 2.05 & 3.65 & 1.28 & 1.60 & 0,001 \\
\hline $\begin{array}{l}\text { Kemampuan Mengontrol } \\
\text { Koordinasi Jari Tangan }\end{array}$ & 1.60 & 2.55 & 1.08 & 1.39 & 0,004 \\
\hline
\end{tabular}

$\mathrm{P}=$ wilcoxon test

\section{PEMBAHASAN}

1. Analisis Kemampuan Mengontrol Lengan

Sebelum dan Sesudah Pemijatan

Analisis data menunjukkan adanya perbedaan kemampuan mengontrol lengan sebelum dan sesudah diberikan perlakuan. Hasil uji dapat disimpulkan bahwa pemberian perlakuan pemijatan dengan cara stimulasi dengan tekanan ringan atau berupa elusan dengan menggunakan telapak tangan atau jari berupa gerakan secara teratur dan berirama pada daerah tubuh dan anggota gerak mempunyai pengaruh terhadap penambahan kemampuan mengontrol lengan pada bayi.

Hasil analisis terhadap selisih ratarata kemampuan mengontrol lengan sebelum dan sesudah pemberian pemijatan memperlihatkan adanya selisih yang besar sehingga pemberian pemijatan pada bayi 
sangat efektif untuk menambah kemampuan mengontrol lengan. Hal tersebut dapat dicapai karena dengan pemberian pemijatan akan merangsang peredaran darah dan merubah energi karena adanya gelombang oksigen yang segar akan lebih banyak dikirim ke otak dan keseluruh tubuh. Pemijatan dapat pula menghasilkan efek biokimia berupa peningkatan kadar serotin yang dapat menghasilkan efek fisik pada bayi berupa pertumbuhan yang optimal sehingga kemampuan mengontrol lengan bertambah. Hal tersebut sejalan dengan pendapat Ina Rosalina (2007) yang menyatakan bahwa pijat dapat mempengaruhi sistem saraf dari tepi sampai ke pusat. Adanya tekanan pada reseptor saraf di kulit akan menyebabkan pelebaran vena, arteri dan kapiler sehingga akan menghambat penyempitan, merileksasikan ketegangan otot, melambatkan detak jantung dan meningkatkan gerakan usus di saluran cerna. Akibat reaksi pemijatan tersebut akan menyebabkan kebutuhan nutrisi meningkat sehingga terjadi pertumbuhan organ dengan optimal terutama sistem motorik sehingga kemampuan bayi untuk mengontrol lengannya bertambah. Dengan demikian dapat disimpulkan bahwa pemberian pemijatan dapat mengoptimalkan pertumbuhan fisik bayi secara tidak langsung khususnya kemampuan mengontrol lengan.

2. Analisis Kemampuan Mengontrol Badan Sebelum dan Sesudah Pemberian Pemijatan Analisis data diperoleh adanya perbedaan kemampuan mengontrol badan sebelum dan sesudah diberikan perlakuan. Hasil uji dapat menunjukkan pemberian intervensi pemijatan dengan cara stimulasi dengan tekanan ringan atau berupa elusan dengan menggunakan telapak tangan atau jari berupa gerakan secara teratur dan berirama pada daerah tubuh dan anggota gerak selama 15 menit berpengaruh terhadap penambahan kemampuan mengontrol badan pada bayi berusia $4-24$ ulan.

Hasil analisis terhadap selisih ratarata kemampuan mengontrol badan sebelum dan sesudah pemberian pemijatan memperlihatkan adanya selisih yang besar sehingga pemberian pemijatan pada bayi sangat efektif untuk menambah kemampuan mengontrol badan. Hal tersebut dapat dicapai karena pada pemijatan dapat mempengaruhi sisten saraf baik saraf tepi maupun pusat. Tekanan pada saraf di kulit akan menyebabkan pelebaran vena, arteri dan kapiler sehingga akan menghambat penyempitan, merileksasikan otot, memperlambat denyut jantung dan meningkatkan gerakan usus di saluran cerna. Pemijatan juga akan meningkatkan hormon katekolamin(epinefrin dan norepinefrin yang berfungsi memacu pertumbuhan bayi sehingga bayi akan lebih cepat menyesuaikan diri dengan lingkungannya sehingga lebih mudah untuk melakukan kontrol terhadap badannya. Pemijatan juga memberikan pengaruh terhadap otot, yaitu terjadinya penarikan ke arah samping dan memanjang. Keadaan tersebut akan meningkatkan mikrosirkulasi yang menyebabkan otot menjadi rileks, fleksibilitas meningkat dan integritas jaringan bertambah serta mudah melepaskan racun sebagai sisa pembakaran sehingga kerja otot semakin baik terutama dalam membantu dan mengarahkan anggota gerak dan tubuh dalam bergerak sehingga mudah terkontrol (Ina Rosalina, 2007). Dengan demikian dapat disimpulkan bahwa pemberian pemijatan dapat meningkatkan kemampuan mengontrol badan bayi.

3. Analisis Kemampuan Mengontrol Tungkai Sebelum dan Sesudah Pemberian Pemijatan Analisis data menunjukkan adanya perbedaan kemampuan mengontrol tungkai sebelum dan sesudah diberikan perlakuan. Hasil uji analisis terhadap selisih rata-rata kemampuan mengontrol tungkai sebelum dan sesudah pemberian pemijatan memperlihatkan adanya selisih yang besar sehingga pemberian pemijatan pada bayi usia $3-24$ bulan sangat efektif untuk menambah kemampuan mengontrol tungkai. Hal tersebut di atas dapat dicapai karena pemijatan dapat mempengaruhi motor learning. Pada dasarnya bahwa proses perkembangan dipengaruhi oleh 4 faktor yakni genetic, maturasi, lingkungan dan kultur. Salah satu factor yang mempengaruhi maturasi adalah reflex dan reaksi motor learning, komponen ini merangsang kematangan atau maturasi pada system saraf ( Donna Cech, 1995). Faktor 
lain yang sangat berpengaruh terhadap pertumbuhan bayi adalah faktor hormonal seperti hipofisis yang akan berpengaruh terhadap pertumbuhan jumlah sel tulang dan hormon tiroid yang berpengaruh terhadap pertumbuhan dan kematangan tulang. Pernyataan tersebut sejalan dengan pendapat Bambang Trijaya (2008) yang menyatakan bahwa perubahan tubuh berlangsung karena pengaruh hormon kelamin dan hipofisi yang pada permulaan terdapat penambahan berat badan disertai dengan penambahan panjang badan. Adanya pertumbuhan terhadap tulang di atas, akan mempengaruhi pada kemampuan anak untuk melakukan aktivitasnya dengan menggunakan tungkai. Penggunaan tungkai pada bayi dengan pertumbuhan tulang yang baik dengan disertai pertumbuhan dan perkembangan pada jaringan otot akan memudahkan anak untuk melakukan gerakan pada tungkainya sehingga bayi tersebut dengan mudah dapat melakukan kontrol terhadap gerakan-gerakan tungkai. Dengan demikian dapat disimpulkan bahwa pemberian pemijatan akan memberikan manfaat yang besar terhadap kemampuan mengontrol tungkai pada bayi usia $6-12$ bulan.

4. Analis Kemampuan Mengontrol Koordinasi Jari Tangan Sebelum dan Sesudah Pemberian Pemijatan

Data yang diperoleh menunjukkan adanya perbedaan kemampuan mengontrol koordinasi jari tangan sebelum dan sesudah diberikan perlakuan. Hasil analisis terhadap selisih rata-rata kemampuan mengontrol koordinasi jari tangan sebelum dan sesudah pemberian pemijatan memperlihatkan adanya selisih yang cukup signifikan sehingga pemberian pemijatan pada bayi usia $3-24$ bulan sangat efektif untuk menambah kemampuan mengontrol koordinasi jari tangan. Hasil analisis tersebut di atas dicapai karena pada pemijatan akan memberikan pengaruh pada anak khususnya pada sistem saraf dan otot. Kemampuan mengontrol koordinasi jari tangan adalah suatu gerakan yang sangat rumit mengingat gerakan pada jari tangan melibatkan banyaknya komponen otot yang bekerja. Pemberian pemijatan pada anak akan mempengaruhi sistem tulang dan otot yang mana kedua sistem tersebut sangat dibutuhkan dalam keterampilan motorik seseorang bayi yang pada prinsipnya berkembang sejalan dengan kematangan saraf dan otot. Terhadap otot, yaitu terjadinya penarikan ke arah samping dan memanjang. Keadaan tersebut akan meningkatkan mikrosirkulasi yang menyebabkan otot menjadi rileks, fleksibilitas meningkat dan integritas jaringan bertambah. Selain itu pemijatan menyebabkan bertambahnya ukuran/dimensi otot akibat bertambahnya sel-sel dan bertambah besarnya sel-sel serta bertambahnya jaringan interseluler (Edwin Tohaga, 2008). Bertambahnya pertumbuhan otot-otot dan saraf pada tangan bayi akan meningkatkan kemampuan koordinasinya sehingga gerakan yang terjadi pada jari tangan dapat dikontrol dengan baik karena adanya pola interaksi yang kompleks dari bagian dan sistem dalam tubuh seperti otot dan sistem tulang/rangka yang di kontrol oleh otak. Dengan demikian dapat disimpulkan bahwa pemberian pemijatan akan memberikan manfaat yang besar terhadap kemampuan mengontrol koordinasi jari tangan pada bayi.

\section{KESIMPULAN}

Pemberian pemijatan bayi usia $3-24$ bulan berpengaruh terhadap peningkatan kemampuan mengontrol lengan, badan, tungkai bawah dan koordinasi jari tangan

\section{UCAPAN TERIMA KASIH}

Terima kasih kami sampaikan kepada Bapak Direktur Poltekkes Makassar, Ketua Jurusan Fisioterapi dan para dosen dan Klinik fisioterapi Sudiang Makassar yang telah memberikan kesempatan untuk melaksanakan penelitian ini, serta orang tua subjek penelitian yang bersedia menjadi responden penelitian ini.

\section{DAFTAR PUSTAKA}

Amelia Amir, 2008, Pengaruh Senam Bayi Terhadap Perkembangan Motorik Kasar Pada Bayi Usia 3 - 12 Bulan di Rsia Sitti Khadijah I Makassar.

Arisman, 2004, Gizi Dalam Daur Kehidupan. Penerbit buku Kedokteran EGC. Jakarta 
Bambang Tridjaya, Si Jangkung dan Si

Pendek, www.ayahbunda-online.com

<Acces at May 4 2016>

Elizabeth B. Hurlock, 1998, Perkembangan Anak, Penerbit Erlangga, Jakarta, hlm. $115-116$

Erwin Tohaga, Deteksi Dini Tumbuh Kembang Anak Kita, www.TripAdvisor.com <Access at April, 3 2016>.

F.J. Monks dkk, 2004. Psikologi Perkembangan. Penerbit; Gajah Mada University Press. Yogyakarta.

Ina Rosalina, 2007, Fisiologi Pijat bayi, Trikarsa Multi Media, Bandung.

Irawan, 2006. Perkembangan Motorik Halus dan Kasar, www. Dokteranakku .com.Diakses Sunday, July 30, 2016.

Irwan Perkembangan Motorik Halus. www.DokterAnakku.com, < acces at September, 2016>

Moersintowarti B.N, 2002, Tumbuh Kembang Anak dan Remaja. Edisi I. IDAI Sagung Seto, Jakarta
Neswroom, Latihan Menulis Untuk Mengembangkan Motorik Halus Anak. www.Mediakita.com <acces at Februari 15, 2016>

Radiarjuni, 2007. Pengaruh Baby Massage terhadap Frekuensi Permintaan ASI Usia 0-6 bulan di Posyandu Cendrawasih Desa Lipukasi Kecamatan Tanete Rilau Kabupaten Barru tahun 2007. Makassar

Soekidjo Notoatmaojo, 1993. Metodologi Penelitian Kesehatan. Penerbit ; Rhineka Cipta. Jakarta.

Soetjiningsih. 1992. Tumbuh Kembang Anak. EGC. Jakarta

Suharsimi Arikunto, 2002. Prosedur Penelitian. Penerbit ; Rhiineka Cipta. Jakarta.

Tiffany Field, 2004, Touch and Massage in Early Child Development, Johnson \& Johnson Pediatric Institute, Miami.

Utami Roesli, 2001. Pedoman Pijat Bayi. Trubus Agriwidya. Jakarta 